\title{
An Expanded Map of Vegetation Communities at Big Muddy National Fish and Wildlife Refuge
}

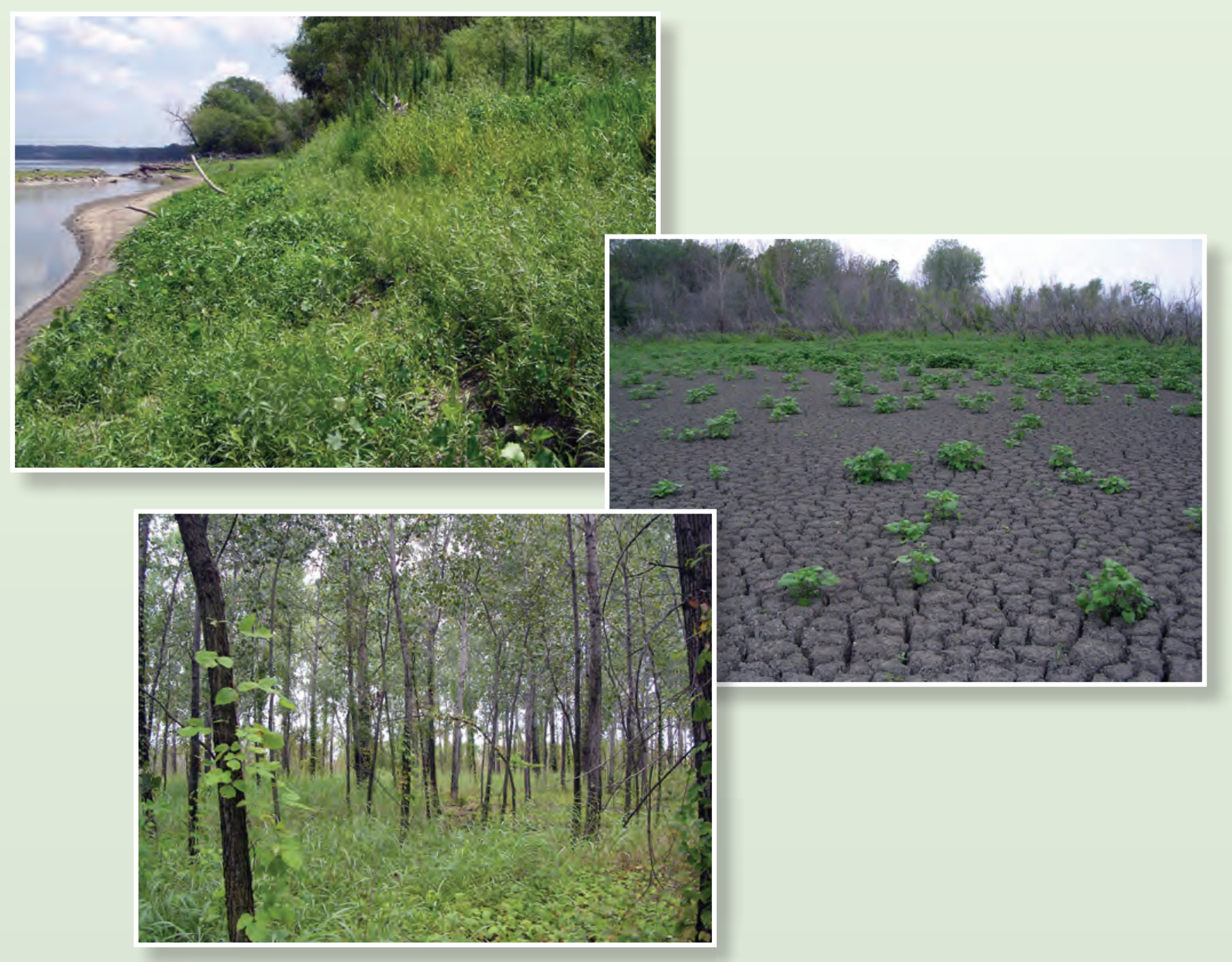

Data Series 785

U.S. Department of the Interior

U.S. Geological Survey 
Cover photographs. Community types documented on Big Muddy National Fish and Wildlife Refuge include (clockwise from top, left) sparse or dense herbaceous vegetation on sand flats adjacent to channels, ephemeral ponds in low lying areas with poorly drained soils, and cottonwood-willow forests on stable floodplains. 


\section{An Expanded Map of Vegetation Communities at Big Muddy National Fish and Wildlife Refuge}

By Matthew A. Struckhoff

Data Series 785 


\title{
U.S. Department of the Interior SALLY JEWELL, Secretary
}

\section{U.S. Geological Survey Suzette M. Kimball, Acting Director}

\author{
U.S. Geological Survey, Reston, Virginia: 2013
}

For more information on the USGS - the Federal source for science about the Earth, its natural and living resources, natural hazards, and the environment, visit http://www.usgs.gov or call 1-888-ASK-USGS.

For an overview of USGS information products, including maps, imagery, and publications, visit http://www.usgs.gov/pubprod

To order this and other USGS information products, visit http://store.usgs.gov

Any use of trade, firm, or product names is for descriptive purposes only and does not imply endorsement by the U.S. Government.

Although this information product, for the most part, is in the public domain, it also may contain copyrighted materials as noted in the text. Permission to reproduce copyrighted items must be secured from the copyright owner.

Suggested citation:

Struckhoff, M.A., 2013, An expanded map of vegetation communities at Big Muddy National Fish and Wildlife Refuge: U.S. Geological Survey Data Series 785, 8 p., http://pubs.usgs.gov/ds/785/. 


\section{Acknowledgments}

Thanks are extended to Wedge Watkins, Tom Bell, and Jestin Clark of Big Muddy National Fish and Wildlife Refuge for logistical support.

Additional gratitude is expressed to my U.S. Geological Survey colleagues: Steve Olson for data collection assistance and Esther Stroh, Keith Grabner, and Robb Jacobson for reviewing an early draft of this manuscript. 


\section{Contents}

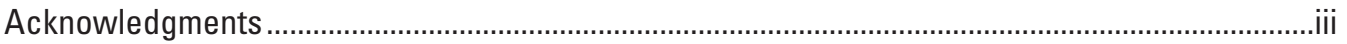

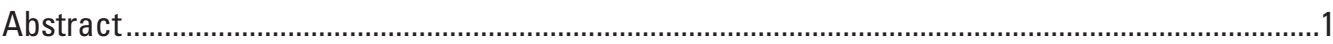

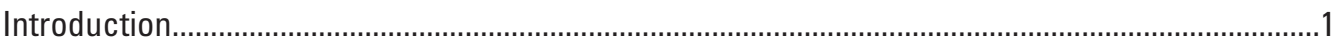

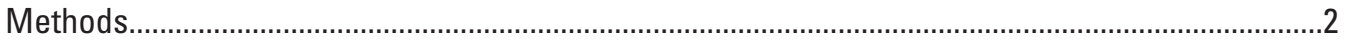

Preliminary Map Aerial Photographic Interpretation ...........................................................2

Field Community Classification ............................................................................................

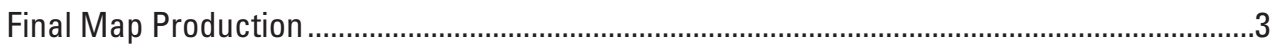

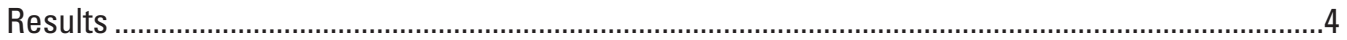

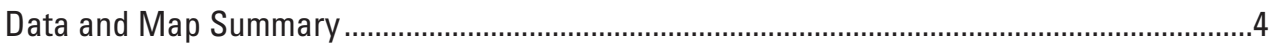

Newly Mapped Communities...............................................................................................6

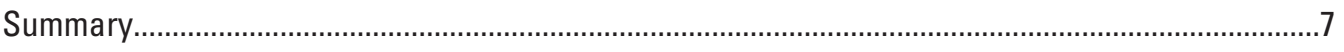

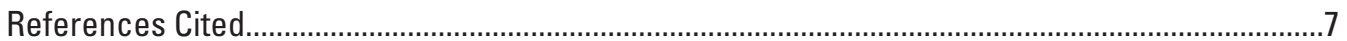

\section{Figures}

1. Map showing units of Big Muddy National Fish and Wildlife Refuge in relation to hydrologically distinct river segments and ecological sections in Missouri

\section{Tables}

1. Cover classes assigned to dominant and exotic species detected at community classification points on Big Muddy National Fish and Wildlife Refuge, Missouri.............3

2. Alphabetical list of exotic species selected for detection during sampling in 2012

3. Mapped vegetation communities at Big Muddy National Fish and Wildlife Refuge arranged by ecological system and decreasing total mapped area 


\section{Conversion Factors}

In/Pound to SI

\begin{tabular}{|c|c|c|}
\hline Multiply & By & To obtain \\
\hline \multicolumn{3}{|c|}{ Length } \\
\hline foot $(\mathrm{ft})$ & 0.3048 & meter $(\mathrm{m})$ \\
\hline mile (mi) & 1.609 & kilometer (km) \\
\hline \multicolumn{3}{|c|}{ Area } \\
\hline acre & 4,047 & square meter $\left(\mathrm{m}^{2}\right)$ \\
\hline acre & 0.4047 & hectare (ha) \\
\hline square foot $\left(\mathrm{ft}^{2}\right)$ & 0.09290 & square meter $\left(\mathrm{m}^{2}\right)$ \\
\hline square mile $\left(\mathrm{mi}^{2}\right)$ & 259.0 & hectare (ha) \\
\hline
\end{tabular}

SI to Inch/Pound

\begin{tabular}{lcl}
\hline \multicolumn{1}{c}{ Multiply } & By & To obtain \\
\hline meter $(\mathrm{m})$ & Length & foot $(\mathrm{ft})$ \\
kilometer $(\mathrm{km})$ & 3.281 & mile $(\mathrm{mi})$ \\
\hline & 0.6214 & \\
\hline square meter $\left(\mathrm{m}^{2}\right)$ & Area & acre \\
hectare (ha) & 0.0002471 & acre \\
square meter $\left(\mathrm{m}^{2}\right)$ & 2.471 & square foot $\left(\mathrm{ft}^{2}\right)$ \\
hectare (ha) & 10.76 & square mile $\left(\mathrm{mi}^{2}\right)$ \\
\hline
\end{tabular}

Horizontal coordinate information is referenced to the North American Datum of 1983 (NAD 83). 



\title{
An Expanded Map of Vegetation Communities at Big Muddy National Fish and Wildlife Refuge
}

\author{
By Matthew A. Struckhoff
}

\section{Abstract}

In 2012, a map of vegetation communities on Big Muddy National Fish and Wildlife Refuge was expanded based on interpretation of aerial photographs and field data. National Agricultural Imagery Program aerial photographs were used to identify distinct communities on previously unmapped refuge units and newly acquired parcels. Newly mapped polygons were then visited to adjust map boundaries, classify communities according to the National Vegetation Classification System, and quantify the abundance of dominant species and non-native, invasive species of concern to the refuge and other resource management agencies along the Missouri River. The expanded map now covers 6,136 hectares representing 33 community types, including 6 previously unmapped types. The full map includes 1,113 polygons, of which 627 are new, 21 are updated from the 2009 mapping effort, and 465 are unchanged from 2009. Mortality of primarily cottonwood stems, because of growing-season floods between 2008 and 2011, has reduced foliar cover of woody stems and created more open wooded communities. In herbaceous communities, dominance by herbaceous old fields has increased due to the inclusion of refuge units dominated by lands in recent agricultural production in the expanded map. Wetland community abundance has increased slightly due to recent flooding.

\section{Introduction}

Big Muddy National Fish and Wildlife Refuge (Big Muddy) is dominantly a valley-bottom refuge comprised of eight disconnected units of Missouri River flood plains and adjacent uplands extending from St. Louis to Kansas City, Missouri. In 2009, a vegetation map (Struckhoff and others, 2011) was generated for five units of Big Muddy (fig. 1) using standards developed by the National Vegetation Classification System (NVCS; The Nature Conservancy, 1994). Mapped community types included 13 natural types identified in the NVCS (NatureServe, 2012), as well as 14 ruderal communities and cultural feature types not recognized by the NVCS but important to management of the refuge. The map included 482 polygons and covered more than 3,100 hectares on the
Boone's Crossing, Saint Aubert's Island, Overton Bottoms, Jameson Island, and Lisbon Bottom units of the refuge within the Ozark Highlands ecological section (fig. 1; Bailey and others, 1994). Units that were left unmapped included Baltimore Bend, Jackass Bend, and Cranberry Bend within the Central Dissected Till Plains ecological section (Bailey and others, 1994) of the river (fig. 1). Subsequent to the mapping in 2009, the previously mapped Overton Bottoms unit has been expanded.

Jacobson and others (2010) described differences between river segments defined by major tributaries believed to affect hydrology, geomorphology, and sediment supply. The Lisbon Bottom, Jameson Island, and Overton Bottoms units are in the Grand segment, between the mouths of the Grand River and the Osage River (Jacobson and others, 2010; fig. 1). The Grand segment is characterized by a stable or aggrading channel bed (Jacobson and others, 2009). The Saint Aubert's Island and Boone's Crossing units are within the Osage segment, downstream from the mouth of the Osage River (Jacobson and others, 2010; fig. 1), which is characterized by an incising streambed (Jacobson and others, 2009). Refuge units within the Kansas segment of the river, between the mouths of the Kansas River and Grand River tributaries (Jacobson and others, 2010; fig. 1) were not mapped. The Kansas segment is characterized by an incising streambed (Jacobson and others, 2009).

The previous map (Struckhoff and others, 2011) was based on field classification data collected during 2007 and a final mapping effort with field verification in 2009. The map identified 31 extant communities on the refuge and an additional 15 NVCS community types either formerly extant or likely to occur within the mapped area (Struckhoff and others, 2011). This report refers to terrestrial natural communities recognized by the NVCS using the NVCS-assigned common name and unique ten digit code in the form "CEGL00\#\#\#\#," with the number signs replaced by the relevant four-digit number (NatureServe, 2012).

Twenty-seven communities were included in the 2009 map (Struckhoff and others, 2011). A few types that were recognized as extant were not mapped because they were encountered infrequently and were smaller than was relevant for management purposes (generally less than 0.25 hectares). The dominant community type was a closed-canopied 


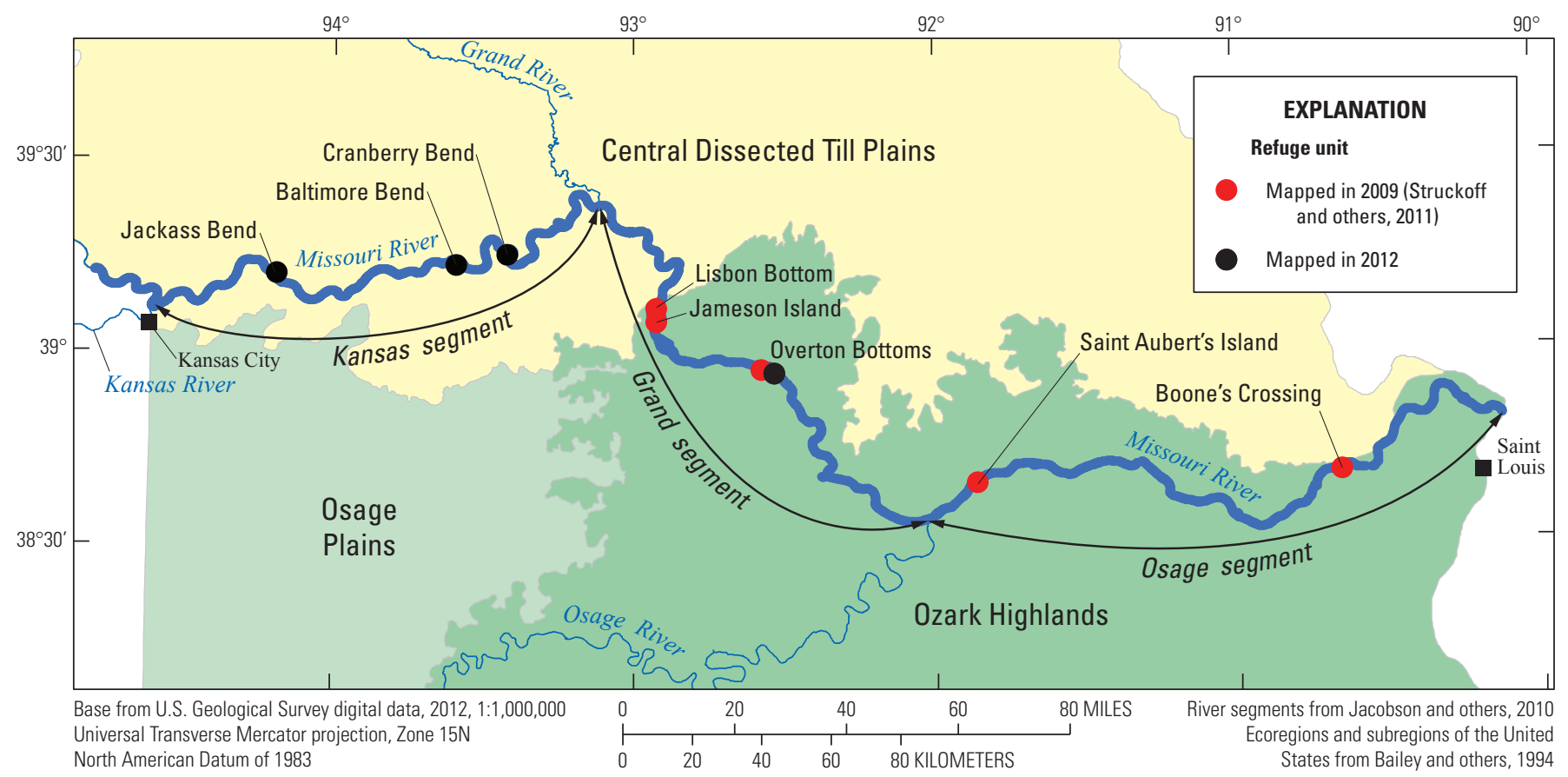

Figure 1. Units of Big Muddy National Fish and Wildlife Refuge in relation to hydrologically distinct river segments (Jacobson and others, 2009) and ecological sections in Missouri.

eastern cottonwood (Populus deltoides) and black willow (Salix nigra) community. This Midwestern Cottonwood-Willow Forest (CEGL002018) covered nearly 60 percent of the mapped area in 2009. The next most abundant community was the open-canopied Cottonwood Floodplain Woodland (CEGL002017), which covered only 7 percent of the mapped area. Most wooded communities were posited to have formed following extreme floods in 1993 and 1995 (Struckhoff and others, 2011). Other common communities included Sandbar Willow (Salix interior) Shrublands (CEGL008562), Riverine Sand Flats (CEGL002430) with sparse or dense herbaceous vegetation on stable sand flats adjacent to the Missouri river and along high-water channels, and herbaceous and woody bottomland fields representing ruderal communities not described by the NVCS (NatureServe, 2012).

As the refuge continues the development of its Comprehensive Conservation Plan, it requires an inventory of extant communities and dominant plant species on the refuge. Additionally, planned application of the Land Capability Potential Index (LCPI; Chojnacki and others, 2012) as a decision support tool for the management of flood plain habitat requires an understanding of the relations between flood plain landforms and plant species and community distributions. This report documents the methods and results of plant community mapping on previously unmapped and newly acquired portions of the refuge in support of these efforts.

\section{Methods}

\section{Preliminary Map Aerial Photographic Interpretation}

Mapping in 2012 was limited to previously unmapped units and newly acquired parcels; no effort was made to update polygons of the original map (Struckhoff and others, 2011), except where these intersected newly mapped areas. Natural color National Agricultural Imagery Program (NAIP) photographs from 2006, 2007, 2009, and 2010, and color-infrared NAIP images from 2009 (U.S. Department of Agriculture, Farm Service Agency, 2012) were used within ArcMap (version 10.1) to delineate communities on recently acquired lands at Overton Bottoms and on previously unmapped refuge units of the Kansas segment of the river (Jacobson and others, 2010) within the Central Dissected Till Plains ecological section (Bailey and others, 1994; fig. 1). The previous mapping effort for the refuge (Struckhoff and others, 2011) and repeated onsite visits to the refuge informed delineation of communities based on color and textural differences visible on the various imagery sets. Onsite visits had indicated that flooding between 2008 and 2011 had caused substantial changes in the structure and composition of many community types; therefore, greater weight was given to more recent photographs. Flooding evident in 2009 and 2010 photographs hindered delineation of herbaceous communities and sand 
flats that were completely inundated, but helped to identify areas that repeatedly experience prolonged inundation likely to affect community composition. The extent of surface water in the photographs also helped to identify low-lying areas in forested communities likely to experience flood-induced woody stem mortality. Apparent boundaries between communities were tentatively mapped with a minimum mapping unit of approximately 0.25 hectares appropriate for management concerns.

No effort was made to classify polygons based on photographic signatures; instead, the final map incorporated classifications and adjustments to polygon boundaries based on field observations of every mapped polygon. This approach yielded a map based on the most up-to-date ground conditions (in contrast to standard methods that yield a map based on quickly outdated photographs of a rapidly evolving landscape with an accuracy report describing known classification errors). The preliminary map for previously unmapped units and newly acquired refuge lands based solely on photointerpretation of community boundaries included 675 new polygons.

\section{Field Community Classification}

Once a preliminary map was completed, at least one sampling point was randomly located within each newly mapped polygon. Multiple points separated by at least 200 meter (m) were placed in all polygons large enough to permit it. This yielded 797 potential community classification points within mapped polygons.

Based on location as determined by a handheld global positioning system (GPS) with 1- to 3- m accuracy, each community classification point was visited and classified to the appropriate community based on the dominant vegetation observed within each polygon during sampling, local and global descriptions of natural community types included in the NVCS (NatureServe, 2012; Struckhoff and others, 2011), and descriptions of ruderal communities and other features not included in the NVCS (Struckhoff and others, 2011). Classification was based on vegetation within an area of approximately 0.2 hectares. Communities that did not match descriptions in Struckhoff and others (2011) were described briefly and given a temporary name until an appropriate NVCS (NatureServe, 2012) or other ruderal community designation could be applied. To aid in final classification, a foliar cover class (table 1) was assigned to the 5 most abundant native species and to any of 22 exotic species identified as important to U.S. Fish and Wildlife refuges and state agencies in the region (table 2). At each point, two photographs were taken with the primary purpose of capturing the range in cover amount or type. Although the azimuth of each photograph was not recorded, obvious landmarks were included in photographs (where possible) to facilitate future photograph-based comparisons. Additional features collected using GPS included transition points between communities (each noting the communities present and the azimuth of the zone of transition) and transects identifying exotic species and community types between classification points. These transition points and transects served as field notes used to inform final community classification and boundary adjustments within a geographical information system.

\section{Final Map Production}

GPS data were compiled using ArcMap (version 10.1) and used as the basis for final delineation of communities. First, notes from transition points and transects were used as the basis for manual adjustment of community boundaries. Where the data and observations supported it, preliminary polygons were joined into larger polygons or subdivided into component units. Then, data from sampling points, photographs, transition points, and transects were used to subjectively classify the community type within the adjusted polygons. Where final classification of the polygon deviated from the classification suggested in the field (as occasionally occurred in polygons with multiple sample points or where there was ambiguity regarding the field classification), the reasoning behind the final classification was included in a comment field for that polygon.

Table 1. Cover classes assigned to dominant and exotic species detected at community classification points on Big Muddy National Fish and Wildlife Refuge, Missouri.

\begin{tabular}{cl}
\hline Value & \multicolumn{1}{c}{ Description } \\
\hline 5 & Dominant species \\
\hline 17.5 & 10 to 10 percent. \\
37.5 & 25 percent. 50 percent. \\
62.5 & 50 to 75 percent. \\
87.5 & Greater than 75 percent. \\
\hline & Exotic species \\
\hline 0 & Not detected. \\
0.01 & Less than 1 percent and less than or equal to \\
& 3 individuals. \\
0.05 & Less than 1 percent and less than or equal to \\
& 3 patches. \\
0.5 & Less than 1 percent. \\
3 & 1 to 5 percent. \\
7.5 & 5 to 10 percent. \\
17.5 & 10 to 25 percent. \\
37.5 & 25 to 50 percent. \\
62.5 & 50 to 75 percent. \\
87.5 & 75 to 100 percent. \\
\hline
\end{tabular}


Table 2. Alphabetical list of exotic species selected for detection during sampling in 2012.

\begin{tabular}{|c|c|c|}
\hline Scientific name and author & Family & Common name \\
\hline Abutilon theophrasti ${ }^{1}$ Medik. & Malvaceae & velvetleaf. \\
\hline Alliaria petiolata $^{1}$ (Bieb.) Cavara \& Grande & Brassicaceae & garlic mustard. \\
\hline Cannabis sativa $\mathrm{L}$. & Cannabaceae & marijuana. \\
\hline Carduus nutans L. & Asteraceae & nodding plumeless thistle. \\
\hline Celastrus orbiculatus Thunb. & Celastraceae & oriental bittersweet. \\
\hline Centaurea stoebe L. ssp. micranthos (Gugler) Hayek & Asteraceae & spotted knapweed. \\
\hline Cirsium arvense (L.) Scop. & Asteraceae & Canada thistle. \\
\hline Elaeagnus umbellata ${ }^{1}$ Thunb. & Elaeagnaceae & autumn olive. \\
\hline Euonymus fortunei (Turcz.) Hand.-Maz. & Celastraceae & winter creeper. \\
\hline Fallopia japonica var. japonica (Houtt.) Ronse Decr. & Polygonaceae & Japanese knotweed. \\
\hline Humulus japonicus ${ }^{1}$ Sieb. \& Zucc. & Cannabaceae & Japanese hop. \\
\hline Lespedeza cuneata ${ }^{1}$ (Dum.-Cours.) G. Don & Fabaceae & Chinese lespedeza. \\
\hline Lonicera maackii (Rupr.) Herder & Caprifoliaceae & Amur honeysuckle. \\
\hline Lythrum salicaria ${ }^{2} \mathrm{~L}$. & Lythraceae & purple loosestrife. \\
\hline Melilotus officinalis ${ }^{1}$ (L.) Lam. & Fabaceae & yellow sweetclover. \\
\hline Microstegium vimineum ${ }^{2}$ (Trin.) A. Camus & Poaceae & Nepalese browntop. \\
\hline Phalaris arundinacea ${ }^{1} \mathrm{~L}$. & Poaceae & reed canarygrass. \\
\hline Phragmites australis ${ }^{2}$ (Cav.) Trin. ex Steud. & Poaceae & common reed. \\
\hline Pueraria montana (Lour.) Merr. var. lobata (Willd.) Maesen \& S. Almeida & Fabaceae & kudzu. \\
\hline Pyrus calleryana Dcne. & Rosaceae & Callery pear. \\
\hline Ranunculus ficaria $\mathrm{L}$. & Ranunculaceae & fig buttercup. \\
\hline Sorghum halepense ${ }^{1}$ (L.) Pers. & Poaceae & Johnsongrass. \\
\hline
\end{tabular}

${ }^{1}$ Recorded at community classification point(s).

${ }^{2}$ Otherwise detected during sampling.

Once all polygons were classified with their boundaries adjusted, the map was examined for irregularities such as unmapped gaps between polygons or overlapping polygons. These were eliminated by manually aligning boundary vertices in the areas of concern. Adjacent polygons classified as the same community type were retained as separate polygons to retain information regarding differences in composition or structure evident during preliminary map production. Such differences may be critical to understanding differences in ecosystem processes between variants of the same community type (for example, between mature cottonwood forests outside of levees and young forests developing on abandoned agricultural lands). Although this potentially inflates estimates of total perimeter for each community type in spatial analyses, this obstacle can be overcome by merging adjacent polygons of the same community type within a geographic information system.

\section{Results}

\section{Data and Map Summary}

Data were collected at 766 community classification points, 145 transition points, and 1,542 transects. These were used to generate an expanded map that now includes 6,163 hectares in 1,113 polygons representing 33 community types. The polygon count and area mapped in each community type are shown in table 3 , which summarizes the 465 polygons unmodified in either shape or classification from the original map produced by Struckhoff and others (2011), the 648 polygons mapped in 2012 (of which 21 were updated from the previous map), and the complete map combining efforts from 2009 and 2012. 
Table 3. Mapped vegetation communities at Big Muddy National Fish and Wildlife Refuge arranged by ecological system and decreasing total mapped area.

[NVCS, National Vegetation Classification System; ha, hectare]

\begin{tabular}{|c|c|c|c|c|c|c|c|c|c|c|}
\hline \multirow{2}{*}{ NVCS $^{1}$ community name } & \multirow{2}{*}{ NVCS code } & \multicolumn{3}{|c|}{ Polygon count } & \multicolumn{3}{|c|}{ Area (ha) } & \multicolumn{3}{|c|}{ Percent of area } \\
\hline & & $2009^{2}$ & $2012^{3}$ & Total & 2009 & 2012 & Total & 2009 & 2012 & Total \\
\hline \multicolumn{11}{|c|}{ Upland forests and woodlands } \\
\hline Black oak-white oak-hickory forest & CEGL002076 & 6 & 0 & 6 & 27 & 0 & 27 & 0.9 & 0 & 0.4 \\
\hline White oak/dogwood dry-mesic forest & CEGL002066 & 4 & 0 & 4 & 21 & 0 & 21 & 0.7 & 0 & 0.3 \\
\hline White oak-alkaline forest & CEGL002070 & 0 & 1 & 1 & 0 & 0 & 0 & 0 & 0 & 0 \\
\hline \multicolumn{11}{|c|}{ Bottomland forests, woodlands, and shrublands } \\
\hline $\begin{array}{l}\text { Midwestern cottonwood-black willow } \\
\text { forest }\end{array}$ & CEGL002018 & 101 & 79 & 180 & 1,800 & 478 & 2,278 & 57.7 & 15.7 & 37.0 \\
\hline Black willow riparian forest & CEGL002103 & 0 & 36 & 36 & 0 & 126 & 126 & 0 & 4.1 & 2.0 \\
\hline Silver maple-elm forest & CEGL002586 & 15 & 10 & 25 & 78 & 21 & 98 & 2.5 & 0.7 & 1.6 \\
\hline Cottonwood-sycamore forest & CEGL002095 & 0 & 10 & 10 & 0 & 48 & 48 & 0 & 1.6 & 0.8 \\
\hline Central wet-mesic tallgrass prairie & CEGL002024 & 4 & 1 & 5 & 37 & 7 & 44 & 1.2 & 0.2 & 0.7 \\
\hline $\begin{array}{l}\text { Ash-oak-sycamore mesic bottomland } \\
\text { forest }\end{array}$ & CEGL002410 & 1 & 3 & 4 & 5 & 7 & 12 & 0.2 & 0.2 & 0.2 \\
\hline Ash-elm-hackberry forest & CEGL002014 & 0 & 1 & 1 & 0 & 1 & 1 & 0 & 0 & 0 \\
\hline \multicolumn{11}{|c|}{ Bottomland herbaceous communities } \\
\hline Midwest ephemeral pond & CEGL002430 & 42 & 75 & 117 & 94 & 174 & 268 & 3.0 & 5.7 & 4.4 \\
\hline Bottomland woody old field & & 9 & 32 & 41 & 35 & 169 & 204 & 1.1 & 5.6 & 3.3 \\
\hline River & & 32 & 13 & 45 & 70 & 75 & 145 & 2.2 & 2.5 & 2.4 \\
\hline Levee & & 11 & 22 & 33 & 12 & 81 & 92 & 0.4 & 2.6 & 1.5 \\
\hline Plantation & & 5 & 6 & 11 & 17 & 47 & 65 & 0.6 & 1.6 & 1.0 \\
\hline Upland woody old field & & 9 & 7 & 16 & 48 & 13 & 62 & 1.6 & 0.4 & 1.0 \\
\hline Johnson grass & & 18 & 9 & 27 & 31 & 30 & 61 & 1.0 & 1.0 & 1.0 \\
\hline Road & & 17 & 15 & 32 & 24 & 11 & 35 & 0.8 & 0.4 & 0.6 \\
\hline Scour & & 1 & 7 & 8 & 9 & 23 & 31 & 0.3 & 0.7 & 0.5 \\
\hline Fescue field & & 4 & 7 & 11 & 14 & 3 & 17 & 0.5 & 0.1 & 0.3 \\
\hline Pond & & 12 & 6 & 18 & 8 & 2 & 10 & 0.2 & 0.1 & 0.2 \\
\hline Railroad & & 3 & 5 & 8 & 8 & 2 & 10 & 0.3 & 0.1 & 0.2 \\
\hline Utility corridor & & 1 & 4 & 5 & 3 & 7 & 10 & 0.1 & 0.2 & 0.2 \\
\hline Total & & 465 & 648 & 1,113 & 3,121 & 3,043 & 6,163 & 100 & 100 & 100 \\
\hline
\end{tabular}

${ }^{1}$ National Vegetation Classification System (The Nature Conservancy, 1994; NatureServe, 2012).

${ }^{2}$ Polygons unmodified from Struckhoff and others (2011).

${ }^{3}$ Includes 627 new polygons and 21 polygons modified from Struckhoff and others (2011). 
Comparison of the results of the 2009 and 2012 mapping efforts reveals a number of differences between mapping years (table 3 ). The mean polygon size in the original map was approximately 6.6 hectares (Struckhoff and others, 2011); the mean polygon size of the expanded map is 5.5 hectares. Possible explanations for the difference in mean polygon size include higher spatial resolution for the newly mapped portions of the refuge, increasing fragmentation of the landscape, and differences in site-level characteristics. Wooded communities with open canopies - defined here to include the Cottonwood Floodplain Woodland (CEGL002017), the Black Willow Riparian Forest (CEGL002103), and the Cottonwood-Sycamore Forest (CEGL002095) -were mapped on a greater percentage of land in 2012 ( 25 percent) than in 2009 ( 7 percent); by contrast, the area mapped as the closedcanopied Midwestern Cottonwood-Black Willow Forest (CEGL002018) decreased from 58 percent to 16 percent. Among herbaceous communities, the largest increases in mapped area between 2009 and 2012 were for the Midwest Ephemeral Pond (CEGL002430), row crops, and old field communities; the largest decreases were for Riverine Sand Flats (CEGL002049).

Examination of the factors affecting the abundance of communities is beyond the scope of this report; however, it is noted here that successional processes and flooding have induced substantial changes in species composition and foliar cover across all refuge units since the previous mapping effort in 2009. Users of the expanded map should be aware that previously mapped areas generally have not been updated to reflect these changes, and that estimates of the abundance of communities based on Struckhoff and others (2011) may not reflect conditions of the vegetation during the 2012 mapping effort.

\section{Newly Mapped Communities}

Seven new community types have been identified as extant on the refuge, of which six were encountered in sufficient size and quantity to warrant inclusion in the final map (table 3). The Central Green Ash-Elm-Hackberry Forest (CEGL002014) is an early- and mid-successional forest dominated by green ash (Fraxinus pennsylvanica), elm (Ulmus spp.), and hackberry (Celtis occidentalis) or sugarberry (Celtis laevigata). This type had been identified at one location during the previous mapping effort, but was excluded from the earlier map due to its small size and similarity to an adjacent silver maple (Acer saccharinum) and elm forest (CEGL002586), a more abundant type on the refuge (Struckhoff and others, 2011). The green ash community tends to occur on stable flood plains; the silver maple community occurs near the Missouri River and along flood-plain drainage features experiencing frequent overland flow. The newly mapped community is of sufficient size and uniqueness to warrant inclusion in the expanded map. Additionally, observations of examples of the Bottomland Woody Old Field (Struckhoff and others, 2011) indicate that the continued trajectory for these communities is toward the green ash-elm-hackberry type (CEGL002014).

Another newly mapped community is the Black Willow Riparian Forest (CEGL002103). The previous mapping effort (Struckhoff and others, 2011) had ultimately classified examples of this type as the dominant Cottonwood-Black Willow Forest (CEGL002018), with which it shares many attributes. Prolonged growing-season floods from 2008 to 2011 have induced widespread mortality among cottonwoods (Populus deltoides), leaving stands dominated by black willow (Salix nigra) that are more appropriately mapped as the Black Willow Riparian Forest (CEGL002103). Cottonwood remains important in the canopy along with sycamore (Platanus occidentalis). Box elder (Acer negundo), mulberry (Morus spp.), and grape vines (Vitis spp.) are abundant in the subcanopy. The ground flora is dominated by poison ivy (Toxicodendron radicans), dock (Rumex spp.), annual sunflower (Helianthus annuus), and Canadian horseweed (Conyza Canadensis). These forests occur on recently abandoned agricultural lands.

The Cottonwood-Sycamore Forest (CEGL002095), another newly mapped forest type, also resembles the Midwestern Cottonwood-Black Willow Forest (CEGL002018). The Cottonwood-Sycamore Forest is not recognized as extant in Missouri by the NVCS, but is indicated as present on large river flood plains in neighboring Kansas (NatureServe, 2012). In this mapping effort, the type is reserved for communities where sycamore is more abundant than cottonwood. Dominant species in the understory, shrub, and ground flora layers are the same as in the Midwestern Cottonwood-Black Willow Forest, and include box elder, mulberry, grape vines, poison ivy, and Canadian horseweed.

Struckhoff and others (2011) described two versions of a stable flood-plain sand-splay community (distinct from the previously mentioned sand flats that receive frequent inundation) that were too small to include in the earlier map. One version was located within a restored Central Wet-Mesic Tallgrass Prairie (CEGL002024) and was dominated by warmseason grasses that had been included in the restoration seed mixture, including big bluestem (Andropogon gerardii), Indian grass (Sorghastrum nutans), and eastern gamagrass (Tripsacum dactyloides). This example of a prairie also included species able to tolerate the seasonally xeric conditions of the sandy substrate, including poorjoe (Diodella teres), prairie tea (Croton monanthogynus), and purple sandgrass (Triplasis purpurea). The other example was located in a cottonwood woodland and was dominated by purple sandgrass, sand dropseed (Sporobolus cryptandrus), and witchgrass (Panicum capillare). Other species included mat sandbur (Cenchrus longispinus), cutleaf evening primrose (Oenothera laciniata), and weedy annuals. The newly mapped 17-hectare example on the Overton Bottoms south unit formed as a result of flooding in 1993 and resembles the latter community, with mat sandbur, prairie dropseed, blue grama (Bouteloua gracilis), prairie tea, and cutleaf evening primrose dominant with annual sunflower, and Canadian horseweed. Though poorly developed, the three examples above collectively approximate the description for 
the Great Plains Riverine Gravel Flats (CEGL005223); that name is applied here as a place-holder for sand-splay communities that appear to form as a result of sand deposition on otherwise stable flood plains during major flood events, such as those in 1993 and 2011.

Another newly mapped herbaceous community is the Midwest Sedge Meadow (CEGL005272). This type represents communities that usually have standing water well into or throughout the growing season (although during the drought of 2012, all four examples of this community type were dry during sampling). Diagnostic species include redroot flat sedge (Cyperus erythrorhizos), rice cut grass (Leersia oryzoides), broadleaf arrowhead (Sagittaria latifolia), and false daisy (Eclipta prostrata). Otherwise, the type shares many dominant species with the Midwest Ephemeral Pond (CGL002430), including cocklebur (Xanthium strumarium) and smartweed (Polygonum spp.). Cottonwood, willow, and buttonbush (Cephalanthus occidentalis) seedlings can be found on exposed mud flats, and in the prolonged absence of flooding can form dense thickets. The prolonged growing-season flood in 2011 appears to have induced widespread mortality in woody thickets found in this type, all examples of which were found at the Jackass Bend unit.

The final newly mapped community is the upland White Oak-Mixed Oak Dry-Mesic Alkaline Forest (CEGL002070), or dolomite forest. Though identified as extant during the 2009 mapping, examples of the type were small (less than 0.25 hectares) and were ultimately mapped as the more common upland White Oak/Dogwood Forest (Struckhoff and others, 2011) with which it was typically associated. The dolomite forest is included in the expanded map because a 0.3 -hectare example was found at Baltimore Bend. Additionally, the effect of dolomite bedrock is evident in the vegetation composition throughout the upland units of the refuge. Although these upland areas represent only 2 percent of a refuge designed to protect Missouri River flood plains, management to support this dolomite forest may become a refuge priority. Diagnostic dominants for this type include white oak (Quercus alba), chinkapin oak (Quercus muehlenbergii), white ash (Fraxinus americana) and sugar maple (Acer saccharum).

One notable extant community excluded from the new map is dominated by the non-native invasive reed canarygrass (Phalaris arundinacea). An example of this provisional type was documented on recently abandoned agricultural lands of the Overton Bottoms south unit and includes dominant species commonly found in the Herbaceous Old Field community described by Struckhoff and others (2011). The type was excluded from mapping because it is not recognized by the NVCS (NatureServe, 2012) and because only one example was found on the refuge such that it did not warrant recognition as a distinct ruderal community type. This fact distinguishes the reed canarygrass community from the abundant Johnson grass (Sorghum halepense) community described and mapped by Struckhoff and others (2011). Nevertheless, reed canarygrass is important to the refuge because it is a noxious weed that can invade open areas and woodlands.

\section{Summary}

The expanded map of Big Muddy National Fish and Wildlife Refuge increases the mapped area from 3,174 hectares (Struckhoff and others, 2011) to 6,136 hectares. Of the 33 community types in the expanded map, 6 were previously unmapped types, including 5 floodplain vegetation communities and 1 upland vegetation community. The full map includes 1,113 polygons, of which 627 are new, 21 are updated from the 2009 mapping effort, and 465 are unchanged from Struckhoff and others (2011).

The expanded map provides an improved assessment of the state of vegetation communities on the refuge that will inform the development of a Comprehensive Conservation Plan for the refuge and will provide an understanding of the extant vegetation communities on the Missouri River flood plain. It should be noted, however, that the mapping effort described here did not attempt to update previously mapped vegetation communities. Given the observed rapid transformation of communities induced by growing-season floods from 2008 to 2011, reassessment of these previously mapped communities would likely improve the development of the refuge conservation plan.

The digital spatial data accompanying this report include the expanded map of vegetation communities at Big Muddy National Fish and Wildlife Refuge and community classification points used to inform map development. Also available are photographs taken at community classification points. Local descriptions of previously mapped communities are available in Struckhoff and others (2011). Global descriptions of all NVCS community types are maintained by NatureServe (2012) and can be accessed online at www.naturserve.org.

\section{References Cited}

Bailey, R.G., Avers, P.E., King, T., and McNab, W.H., eds., 1994, Ecoregions and subregions of the United States (map): Washington, D.C., U.S. Geological Survey, 1:7,500,000. Colored. [Accompanied by a supplementary table of map unit descriptions compiled and edited by McNab, W.H. and Bailey, R.G. Prepared for the USDA Forest Service].

Chojnacki, K.A., Struckhoff, M.A., and Jacobson, R.B., 2012, Land Capability Potential Index (LCPI) and geodatabase for the Lower Missouri River Valley: U.S. Geological Survey Data Series 736, 18 p.

Jacobson, R.B., Blevins, D.W., and Bitner, C.J., 2009, Sediment regime constraints on river restoration-An example from the Lower Missouri River: Geological Society of America Special Paper, v. 451, p. 1-22. 
Jacobson, R.B., Elliott, C.M., and Huhmann, B.L., 2010, Development of a channel classification to evaluate potential for cottonwood restoration, lower segments of the Middle Missouri River, South Dakota and Nebraska: U.S. Geological Survey Scientific Investigations Report 2010-5208, 38 p.

NatureServe, 2012, NatureServe Explorer-An online encyclopedia of life [web application], Version 7.1: Arlington, Virginia, NatureServe, accessed December 2012, at $w w w$. natureserve.org/explorer.

The Nature Conservancy, 1994, Standardized national vegetation classification system-Report to U.S. Department of Interior: Arlington, Virginia, The Nature Conservancy and Environmental Systems Research Institute, 94 p., plus appendixes.
Struckhoff, M.A., Grabner, K.W., and Stroh, E.D., 2011, Vegetation Communities at Big Muddy National Fish and Wildlife Refuge, Missouri, U.S. Geological Survey OpenFile Report 2011-1038, 29 p.

U.S. Department of Agriculture, Farm Service Agency, 2012, National Agriculture Imagery Program: U.S. Department of Agriculture, Farm Service Agency, accessed March, 2012, at www.fsa.usda.gov/FSA/apfoapp?area=home\&subject=pr og\&topic=nai.

Publishing support provided by:

Rolla Publishing Service Center

For more information concerning this publication, contact:

Director, USGS Columbia Environmental Research Center

4200 New Haven Road

Columbia, MO 65201

(573) 875-5399

Or visit the Columbia Environmental Research Center Web site at:

http://www.cerc.usgs.gov/ 



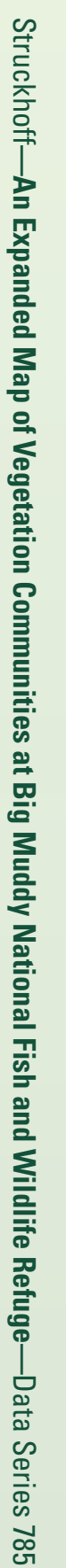

